\title{
Atypical Achy Breaky Heart
}

\author{
Samantha Gelman*, Andrew Benin, Gregory Shimizu, Scott Kubomoto and Rajesh Gulati \\ RCH Community Hospital, USA
}

*Corresponding author: Samantha Gelman, RCH Community Hospital, USA

\begin{tabular}{|c|c|}
\hline ARTICLE INFO & ABSTRACT \\
\hline Received: 幽 February 13, 2020 & Citation: Samantha Gelman, Andrew Benin, Gregory Shimizu, Scott Kubomoto, Rajesh \\
\hline Published: 幽 February 21, 2020 & $\begin{array}{l}\text { Gulati. Atypical Achy Breaky Heart. Biomed J Sci \& Tech Res 25(5)-2020. BJSTR. } \\
\text { MS.ID.004267. }\end{array}$ \\
\hline
\end{tabular}

\section{Opinion}

Takotsubo cardiomyopathy is a transient left ventricular systolic dysfunction that presents similar to myocardial infarction and is commonly misdiagnosed as secondary to acute coronary syndrome (ACS) from atherosclerotic heart disease. It is found in $1-2 \%$ of patients who present with suspected ACS or STEMI. Emotional stressors are found in 39\% of patients and physical stressors are found in 35\%. Takotsubo cardiomyopathy typically presents with ST segment elevation in $43.7 \%$ of patients and most commonly affecting the anterior precordial leads. We present an atypical case of Takotsubo cardiomyopathy.

\section{Case Description}

A 64-year-old female with a history of colon cancer and breast cancer, in remission presented with chest pain that started while she was at church. The onset was sudden, 5 out of 10 in severity, with radiation to the back. There was no emotional stressor. On admission, the patient's chest tightness resolved with nitroglycerin. Troponin was $2.63 \mathrm{ng} / \mathrm{dL}$ and the initial diagnosis was NSTEMI. BNP was elevated at $855 \mathrm{pg} / \mathrm{mL}$ and EKG findings were consistent with an inferolateral ischemia, with a prolonged QT interval. A 2D echocardiogram showed a normal left ventricular size and systolic function with an ejection fraction estimated to be $55 \%$ to $65 \%$, without regional wall motion abnormalities, wall thickness at the upper limits of normal, pericardium demonstrated a trivial, loculated pericardial effusion posterior to the heart, cardiac catheterization/ angiography findings included a normal left end-diastolic pressure with left ventricular ejection fraction of $45 \%$ to $50 \%$ and associated apical hypokinesis, without evidence of coronary artery disease consistent with probable Takotsubo syndrome associated with a coronary spasm. The patient underwent medical management with aspirin, lisinopril, carvedilol, and atorvastatin.

\section{Discussion}

Takotsubo syndrome derives its name from the Japanese word for octopus pot, because on imaging the left ventricle demonstrates a narrow neck and a round bottom similar in shape to pots used in fishing for octopus. Takotsubo syndrome is typically stress induced (emotional or physical). This patient had an atypical presentation of Takotsubo where the diagnosis on admission was NSTEMI without any associated left ventricular systolic function or emotional stressor. Due to limited literature, many of these cases are overlooked and treated as a myocardial infarction with a new onset diagnosis of coronary artery disease (CAD) rather than a reversible cardiomyopathy with no cardiac sequelae. When evaluating patients with NSTEMI without any history of CAD, Takotsubo cardiomyopathy should be included as part of the differential diagnosis. 
ISSN: 2574-1241

DOI: 10.26717/BJSTR.2020.25.004267

Samantha Gelman. Biomed J Sci \& Tech Res

(c) (P) This work is licensed under Creative

Submission Link: https://biomedres.us/submit-manuscript.php

$\begin{array}{ll}\text { BIOMEDICAL } & \text { Assets of Publishing with us } \\ \text { RESEARCHES } & \text { Global archiving of articles } \\ \text { - Immediate, unrestricted online access } & \text { - Rigorous Peer Review Process } \\ & \text { - Authors Retain Copyrights } \\ \end{array}$

